

\section{Theory and events}

The 'Arab Spring', the mobilization for democratic change inaugurated by political upheaval in Tunisia, then Egypt, and rumbling along from Bahrain to Yemen, Syria to Jordan, has elicited an enormous amount of instant interpretation, not least through the rapidly burgeoning academic blogosphere. My relation to these events, no doubt like those of many others, has been one of passive witness. Witnessing has a 'retroactive' temporal structure, in which one becomes aware of things one took little notice of as one is placed under a responsibility to attend them in new ways (Peters 2001). Responding to this experience of being positioned as a mediated witness, then, opens up the question of how to articulate one's experience of learning new things.

For many academic commentators, the Arab Spring has often confirmed existing commitments. For some, these events represent a continuation or reactivation of a democratic revolution inaugurated in 1989. For others, they echo the democratic experiments which emerged in Latin America in the last decade and a half, and confirm the political potential of 'the multitude'. For others, the lesson is really about the wholly new form of politics that social media and digital communications open up.

While some forms of theory find their favourite themes confirmed by these events, others have had their authority severely strained. As civil war developed in Libya in February, the London School of Economics was embroiled in controversy about its links with the Gaddafi regime - via the award of Saif Gaddafi's $\mathrm{PhD}$, but more consequentially through the acceptance of 'tainted money' to help finance a programme of research on governance and civil society in North Africa. It turns out, although never having been a secret, that political thinkers including David Held, Anthony Giddens, Benjamin Barber, and Robert Putnam have been variously involved with the Qadaffi Foundation, as part of a broader 'normalisation' of relations with Libya, around nuclear weapons and the 'war on terror' in particular. Other thinkers, such as Todd Gitlin, John Keane, and Anthony Barnett all 
helpfully pointed fingers of accusation. The speed with which the LSE's already existing and quite open relationship with Libya became a reputational burden as civil war embroiled that country is indicative of how the moral transparencies of media framing can, under certain circumstances, overwhelm institutions. The same moralized frame that de-legitimized the LSE's dealing with the Gaddafi regime has shaped the rapid move to NATO-led 'humanitarian intervention' in the Libyan conflict.

Amongst all the excitement about the role of new media in Tunisia or Egypt, there was also a degree of skepticism. In response, Jay Rosen (2011) identified a whole new genre of journalism, which he dubbed 'The twitter can't topple dictators' article. He suggested this style of nay saying actually closes down serious the question of how the Internet does affect contentious political processes: "A real grown-up understands that the question is hard, that we need facts on the ground before we can start to answer it. Twitter brings down governments is not a serious idea about the Internet and social change. Refuting it is not a serious activity. It just feels good... for a moment." In fact, the focus on the role of the media served as an occasion through which changing forms of organization, long-term processes of dissent or class restructuring, or changing social relations of ethnicity or gender become visible as commentators seek to situate the influence 'media' may or may not play. Research on the relationship of digital communications and social media to contentious politics emphasizes the layered temporalities through which this relationship is itself mediated - via reconfigurations of individual subjectivities, intergroup relations, collective action repertoires, regime policies, and external attention (Adey et al 2010).

Media theorists have a tendency to find in these real-time revolts confirmation for some of their favourite hypothesis, but this focus on mediums practice inevitably opens itself up to other forms of contextual and causal understanding. 'Philosophical' interpretations of the Arab Spring are not marked by the same opening out to empirical modesty. The concept of 'event' has become a hot topic in certain strains of what has become canonized, wholly without irony, as 'Continental 
Philosophy'. Inflected by the thought of Derrida, Deleuze, Badiou, and others, the event is a figure for the surprising, unforeseen, ruptural, and, perhaps, the relation of the 'exciting' to the more routine, entrained, predictable (see Connolly 2011). It's also become, in some usages, a smart way of keeping alive a messianic fantasy of political revolution. There is a danger involved here in inviting us to mistake something that happens to surprise us for a grand ontological 'event', thereby projecting one's own previous ignorance or inattention into the structure of the world.

It has been interesting given all the talk of 'the event' on the theory-left, to see the leading figures of 'Continental Philosophy' expound on the political upheavals sweeping North Africa and the Middle East these last few months. What is notable is how many of these commentaries manage to find exactly what they want to find in Tunisia, or Egypt, or Libya, especially if it's confirmation of the purity of 'the event'. Alain Badiou saw in Tunisia and Egypt a confirmation of his own version of 'the communism of movement'. Badiou's (2011) anti-Orientalist-Orientalist-romanticization of 'Eastern winds' led him to suggest that "The word "democracy" is hardly uttered in Egypt". He must have been watching different TV pictures to the rest of us. Badiou chose to emphasize those aspects of these events - their illegality, there apparent spontaneity and lack of leadership (a recurrent observation), and in his view the simple confrontation of 'the state' versus 'the people' that lend themselves best to his own vision of revolutionary possibility. Picking up Badiou's analysis of the event, Peter Hallward (2011) was one amongst many who insist upon inscribing the Arab Spring into broader narratives of a revolt against neoliberalism (thereby mistaking a causal condition for a motivating reason). Hallward was concerned to affirm that Tunisia and Egypt both met the criteria of proper revolutions, understood in faintly vanguardist terms as occasions when "the will of the people is sustained through the practice of those who compose and impose it in the collective interest". In trying to make this case stick, it turns out that some revolutions are more revolutionary than others. Hallward feels that the democratic revolutions of 1989 in Central and Eastern Europe, and the subsequent ‘colour revolutions' over the ensuing two decades, don't quite count as proper revolutions, since these have been "uprisings that served mainly to consolidate 
rather than challenge the global status quo". Quite how precipitating the collapse of the Soviet Union consolidated the global status quo is not made clear.

In these sorts of philosophical commentaries, events in Tunisia or Egypt are swept up into a mythical figure of 'revolution' with a capital R, undertaken by 'the people' with a capital P. Pressing very real democratic revolutions into this mythical, utopian image of Revolution manages to occlude the question of who the living subjects of these events actually are (Salvatore 2011). The know-nothing-ism that undergirds this revolutionary universalism was given clearest expression by Slavoj Žižek’s (2011) interpretation of the uprising in Egypt: “The uprising was universal: it was immediately possible for all of us around the world to identify with it, to recognize what it was about, without any need for cultural analysis of the features of Egyptian society. In contrast to Iran's Khomeni revolution (where leftists had to smuggle their message into the predominantly Islamist frame), here the frame is clearly that of a universal secular call for freedom and justice, so that the Muslim Brotherhood had to adopt the language of secular demands." There is something wonderfully self-aggrandizing about this assertion, which arrogates interpretative authority to a cadre of bombastic philosophical Universalists who don't have to worry about what they do and don't know about other places.

For Žižek, of course, no example of actually existing progressive politics is ever enough; human rights, multiculturalism, non-violence, ecology - all these and many other modes of active engagement with the world of politics and power are always already condemned to fall short of total transformation. So it is, too, in the case of Egypt. Žižek was quick to pronounce that unless 'the whole edifice' fell, the uprising would have been ‘co-opted and betrayed'. Badiou's and Žižek’s pretension has been met with some caustic criticism from within Theory-land. The Tunisian born intellectual Mehdi Belhaj Kacem (2011) rebuked Badiou's disdain for 'democracy' by noting that “the words 'freedom' and 'democracy' were heard more in the Arab world than in the previous forty years" following the Tunisian uprising in January, dismissing Badiou and Žižek for knowing 
“absolutely nothing about the situation”. The presumed journalistic transparency of worldly politics to immediate, philosophical interpretation is in fact indicative of resurgent style of metaphysical reasoning in certain strains of Theory (see Hunter 2010). The reassertion of the authority of philosophical reason over the merely 'ontic' level of social science presumes that philosophical concepts derived from eccentric readings of Set Theory or a classical European tradition of metaphysics require no mediation whatsoever by concepts of empirical social science. In this conception of philosophy, worldly 'events' are only ever the expression of processes whose truth is best grasped by purely speculative reflection.

Meanwhile, theory of a different sort turns out to have played an active part in these political events. Amidst the uprising that overthrew Hosni Mubarak in Egypt, Gene Sharp, political theorist of non-violence, was profiled in a range of after-the-fact reflections on political upheaval in Tunisia and Egypt in particular. Sharp was mentioned in a New York Times article about these revolutions, and was then the subject of a follow-up profile. Interviews and blog notices about his influence in shaping the non-violent strategies of protestors quickly circulated. Sharp is often a focus of attention when non-violent political action shakes more or less dictatorial, more or less authoritarian regimes around the world - he is credited with influencing non-violent political movement from Burma to Zimbabwe, Iran to the Ukraine. Sharp's (2010) analysis of non-violent political action rests on the idea that the power of rulers lies in the obedience and co-operation of their subjects, rather than being premised on violence. The idea is not meant as an idealization, but serves as the basis of a strategically nuanced understanding of the relationship between violence, non-violent protest, and state structure that has informed and been informed by the histories of contemporary civil resistance (Roberts and Garton-Ash 2010).

If Sharp's ideas were one example of academic work being thrown into new perspective by 'events', then the Arab Spring also disclosed a wealth of social science and social theory informed by sustained engagement with the politics and life of this region. Belying the simplistic view of 
these democratic revolutions as expressions of universal concepts of Revolution, informed treatments of the cultural politics of Egyptian public life, for example, focus on a longer-term reconfiguration of religious practice and political community. The anthropologist Charles Hirschkind (2006) has provided a detailed ethnographic account of the importance of taped sermons in shaping contemporary Islamic public spheres. The ongoing importance of media technologies, in Hirschkind's account, lies in the practices of self that can be sustained and circulated through a mediated culture of listening and of being devout. In his own blog-commentary on events in Egypt, Hirshckind (2011) locates the significance of new media like blogging in this longer durée of cultural change, helping to shape the cultivation of new spaces of pluralism and new conditions for organizing.

Hirschkind's analysis reminds us that it is best not to reduce the political significance of new media, or old media for that matter, to the temporality of the moment, to that of 'the event'. He also indicates that media spaces are intimately folded into urban spaces. The pluralist space of blogging he describes is closely related to more classical spaces of political action: "bloggers understand their role as that of providing a direct link to what they call "the street", conceived primarily as space of state repression and political violence" (see also Ghannam 2011, Al Saleh and Arefin 2011). The 'street', however, is a complex image in this context, and perhaps here too there is reason to avoid a fetishization of 'real' or 'physical' space as the scenes of robust political action (despite their location, these have not been political movements staking claims of a 'right to the city', but have mobilized resolutely nationalist registers in re-asserting popular sovereignty). Hirschkind's analysis suggests that the conjunctural role of media practices in dramatic political change needs to be placed within longer temporal processes of urbanization and even of urbanity. A year or so ago I listened to a talk at a workshop by the Egyptian academic and activist Heba Raouf Ezzat, who talked about the vibrant but furtive quality of the political public sphere in Egypt. She made use of the work of Asef Bayat (2010), who has written about new 'post-Islamic' social movement politics and the ordinariness of political action in the Middle East. Rather than thinking of the Arab Spring 
as a wholly unprecedented, unpredictable events or set of events, Bayat's work suggests a need to consider contextual factors, conditions, and causal processes. For Bayat, events in Tunisia and Egypt and beyond are indicative of processes of rapid urbanization, and the associated sociocultural developments of increasingly literacy, high levels of education, professionalization, changing gender relations, the emergence of a middle-class poor and other new forms of inequality and, yes, the development of new media cultures. In this perspective, 'the Arab street' (Bayat 2011) is a complex figure of ideas and practices about the force of popular opinion, the fragility of state power, and the calibration of formal political processes to material conditions of life (what Africanist political theorists might call 'the politics of the belly' or 'the politics of suffering and smiling').

As a subject of the mediated representation of events at once inspiring and appalling, surprising and predictable, the Arab Spring has been the occasion for learning how much I didn't know about these places, as well as being reminded of some things I did know but had forgotten about. Of course, I'm drawn to the ideas of Hirschkind or Bayat because they seem to confirm some of my own favourite hypotheses, although these are more like questions than answers. These sorts of ethnographic analyses of the spaces of political action are helpful in indicating the extent to which democratic energies might be understood as urbanized in certain respects, without forcing one to fetishize a particular romantic image of the city as the scene of political life. There is an urbanity to contemporary movements for democratic change in Egypt, Tunisia, Iran and elsewhere, it seems: in so far as they are peopled by labour activists, and professional classes, by women's organizations, as well as by varieties of religious activism which are resolutely modern in their concerns and 'secular' in novel ways. It seems too that there might be something resolutely urbanized about the 'conjunctural' factors at work in these recent events - the central importance of economic grievances over unemployment and food prices is indicative of the interplay between spatially extensive infrastructures of provisioning upon which contemporary urban living on the scale of a 
city like Cairo depends, and the more contained, lived and shared experiences of stunted citizenship.

The Iranian scholar Hamid Dabashi (2011) heralded the political uprisings in North Africa and the Middle East, and including the darker turn of events taken in Libya, as marking 'a new imaginative geography of liberation'. These events, he suggests, disrupt both discourses of the West versus Islam, but also orthodox postcolonial alibis that underwrite the anti-Orientalist Universalist interpretations purveyed by theorists of 'the event'. The responsibility of distant witness is to hold open the questions that arise from being presented with one's own ignorance and indifference, and to listen to voices which might better understand the dynamics of this new geography.

\section{References}

Adey, S., Farrell, H., Lynch, M, Sides, J., Kelly, J., and Zuckerman, E. 2010. Blogs and Bullets: new media in contentious politics. Washington, DC: United States Institute of Peace.

Al Saleh, D. and Arefin, R. 2011. Five days of anger: revolt in the modern metropolis. http://www.thepolisblog.org/2011/01/five-days-of-anger-revolting-in-modern.html Accessed February 28th 2011.

Badiou, A. 2011. The wind of the East carries away the wind of the West. http://www.lacan.com/thesymptom/?page_id=1031 Accessed 12th February 2011.

Bayat, A. 2010. Life as Politics: How Ordinary People Change the Middle East. Stanford: Stanford University Press.

Bayat, A. 2011. A new Arab Street in post-Islamist times. http://mideast.foreignpolicy.com/posts/2011/01/26/a_new_arab_street Accessed February $4^{\text {th }}$ 2011.

Connolly, W. 2011. The politics of the event. http://contemporarycondition.blogspot.com/2011/04/politics-of-event.html Accessed April $4^{\text {th }}$ 2011. 
Dabashi, H. 2011. Delayed defiance.

http://english.aljazeera.net/indepth/opinion/2011/02/2011224123527547203.html Accessed 2nd March 2011.

Ghannam, F. 2011. Space and resistance. http://blogs.ssrc.org/tif/2011/02/08/space-and-resistance/ Accessed $9^{\text {th }}$ February 2011.

Hallward, P. 2011. Arab uprising marks a turning point for the taking.

http://www.guardian.co.uk/commentisfree/2011/feb/22/arab-uprisings-world-order-middle-east Accessed 12th February 2011.

Hirschkind, C. 2006. The Ethical Soundscape: Cassette Sermons and Islamic Counterpublics. New York: Columbia University Press.

Hirschkind, C. 2011. The road to Tahrir. http://blogs.ssrc.org/tif/2011/02/09/the-road-to-tahrir/ Accessed $9^{\text {th }}$ February 2011.

Hunter, I. 2010. Scenes fro the history of poststructuralism: Davos, Freiburg, Baltimore, Leipzig. New Literary History 41, 491-516.

Kacem, M. B. 2011. A Tunisian Renaissance. http://www.lacan.com/thesymptom/?page_id=1046 Accessed 11th March 2011.

Peters, J. D. 2001. Witnessing. Media, Culture and Society 23, 707-723.

Roberts, A. and Garton-Ash, T. 2010. Civil Resistance and Power Politics: the experience of nonviolent action from Gandhi to the present. Oxford: Oxford University Press.

Rosen, J. 2011. The “twitter can't topple dictators” article. http://pressthink.org/2011/02/the-twittercant-topple-dictators-article/ Accessed 12th February 2011.

Salvatore, A. 2011. The elusive subject of revolution. http://blogs.ssrc.org/tif/2011/02/16/theelusive-subject-of-revolution/ Accessed March 20 2011.

Sharp, G. 2010. From dictatorship to democracy: A conceptual framework for liberation, $4^{\text {th }}$ Edition. Boston, MA: The Albert Einstein Institution. 
Žižek, S. (2011). For Egypt, this is the miracle of Tahrir Square.

http://www.guardian.co.uk/global/2011/feb/10/egypt-miracle-tahrir-square Accessed 12th February 2011. 